\title{
Habitat dependence in the functional traits of Austrohelice crassa, a key bioturbating species
}

\author{
H. R. Needham ${ }^{1,2, *}$, C. A. Pilditch ${ }^{1}$, A. M. Lohrer ${ }^{2}$, S. F. Thrush ${ }^{2}$ \\ ${ }^{1}$ Department of Biological Sciences, University of Waikato, Private Bag 3105, Hamilton, New Zealand \\ ${ }^{2}$ National Institute of Water and Atmospheric Research, PO Box 11-115, Hamilton, New Zealand
}

\begin{abstract}
Bioturbating macrofauna can have major effects on their physical, biological and biogeochemical surroundings, altering ecosystem functioning. Burrow builders increase the amount of sediment-water interface over which oxidative exchange occurs, whilst organisms that 'bulldoze' through sediments homogenise and oxygenate the surface layers. Here we demonstrate that the bioturbating crab Austrohelice crassa performs the role of burrow builder in muddy and bulldozer in sandy sediments. Sediment reworking rates and expansion of the sediment-water interface through A. crassa bioturbation were estimated from 4 parameters: burrow and crab density, burrow morphology, burrow permanency, and burrow maintenance, measured across a sedimentary gradient. Burrow decay rates $\left(k, \mathrm{~d}^{-1}\right)$, in combination with differences in burrow and crab densities, were responsible for changes in sediment reworking rates among habitats. Mean burrow permanency $(1 / k)$ varied from $25.7 \mathrm{~d}$ in mud to $10.8 \mathrm{~d}$ in muddy sand to $1.4 \mathrm{~d}$ in sand. In mud, where adult burrow density was greatest $\left(207 \mathrm{~m}^{-2}\right)$ and structures were stable, A. crassa burrows extended the sediment-water interface by $147 \%$, compared with $50 \%$ in muddy sand and $22 \%$ in short-lived sand burrows. In sand, $82 \%$ of the sediment available to A. crassa was mixed per lunar month (rising to $130 \%$ when including burrow maintenance values), whereas in mud and muddy sand, mean rates of sediment reworking dropped to $7.4 \%$. These differences in the key bioturbational role of A. crassa between sediment types indicate that the impact of this species on ecosystem functioning will be highly habitat-dependent.
\end{abstract}

KEY WORDS: Austrohelice crassa · Bioturbation · Functional plasticity · Burrow permanency

\section{INTRODUCTION}

Soft-sediment environments are the most common habitats on the planet (Snelgrove 1999). Intertidal areas form only a small percentage of these environments, but offer a heterogeneous matrix of sedimentary and hydrodynamic conditions for macrofauna. Many macrofaunal species display some degree of habitat selectivity due to their lifestyle or trophic mode and patterns of organism distribution differ across sediment gradients (Levinton \& Kelaher 2004). The activity and behaviour of some macrofaunal species can have disproportionate effects on their environment, relative to their body size, by influencing processes such as sediment transport, carbon trapping, primary production and nutrient regeneration, which are often measured as indicators of ecosystem functioning (Widdicombe \& Austen 1998, Lohrer et al. 2004, Webb \& Eyre 2004, Thrush et al. 2006). Organism morphology and behaviour have been used to group species according to their functional traits to infer impacts on ecosystem processes (Tilman 2000, Hewitt et al. 2008). However, habitat-mediated differences in functioning of an individual species have not been considered in the application of functional trait analyses.

Bioturbating macrofauna (i.e. species that alter their sedimentary environment through their movement) often play a key role in ecosystem functioning (Mullan Crain \& Bertness 2006 and references therein) and are commonly categorised as either bulldozers or burrow builders. Bulldozers perpetually move through the sediment matrix below the surface disturbing the top 
few centimetres of sediment. Organisms that perform this mode of bioturbation (e.g. heart urchins) alter the sediment matrix through increased oxygen penetration and, as sediment is destabilised through their movement, organic matter is subducted, stimulating remineralisation and porewater release (Osinga et al. 1997, Hollertz \& Duchêne 2001, Lohrer et al. 2004). In contrast, burrow builders create structures in which they live more or less permanently or use as a refuge from predation and environmental stress. Burrowbuilding fauna primarily mediate change to the sediment environment through the extension of the sediment-water interface, increasing the area available for oxidative exchange to take place. Burrows increase microorganism habitat and enable translocation of particles to different reaction zones through non-local mixing and sediment trapping, altering remineralisation rates (Aller \& Yingst 1978, Kristensen et al. 1985, Botto \& Iribarne 2000)

Grouping organisms according to their functional traits enables predictions of their broad-scale influences on ecosystem functioning. Methods for evaluating ecological functioning, such as trophic group, biological trait and functional group analysis, are evolving as ecosystem-based management tools (Roth \& Wilson 1998, Bonsdorff \& Pearson 1999, Bremner et al. 2006). These approaches are supported by natural history information and data from small-scale studies investigating the influence of bioturbators on ecosystem rates and processes. However, such studies are often conducted without exploring the underpinning mechanisms by which the observed changes were mediated. For instance, although many studies have linked patterns in nutrient exchange to the density of burrowing organisms, alterations in species behaviour or burrow structure created by their increased proximity to one another are not often addressed (D'Andrea \& DeWitt 2009). Similarly, with bulldozing macrofauna, many studies have linked changes in rates and processes to their presence, but have not quantified sediment reworking rates to support their findings (Lohrer et al. 2005). Organism behaviour, sediment type and interactions between both factors have the potential to mediate changes to ecosystem functioning.

Many crustaceans, including several burrowing crab species, have proven to be functionally important in intertidal habitats (Lee 1998, Kostka et al. 2002, McCraith et al. 2003, Botto et al. 2005, Gutierrez et al. 2006, Fanjul et al. 2008, Kristensen 2008 and references therein). The impact of these crabs on ecosystem functioning is likely to be related to their density, activity, burrow morphology and permanency (i.e. the rate at which burrows collapse and are rebuilt), factors that are likely to vary among species and sediment type. While variations in crab density and burrow morpho- logy with sediment type and shore position have been well documented (Takeda \& Kurihara 1987, Lim \& Diong 2003, Mouton \& Felder 1996, Iribarne et al. 1997, Morrisey et al. 1999, Breitfuss 2003, Salgado Kent \& McGuinness 2006), sediment reworking rates have rarely been quantified (Katz 1980, Gardner et al. 1987, Wolfrath 1992, Botto \& Iribarne 2000, McCraith et al. 2003). Measurements of sediment reworking are important when defining bioturbatory activity of an organism in its environmental context. Whilst a burrower's bioirrigation capacity is suggested by the increase in sediment-water interface created through burrow building, if the burrow collapse rate is high, the overriding functional significance of the species may be mediated through increased sediment turnover. For example, McCraith et al. (2003) demonstrated that the rate of fiddler crab burrow turnover was linked to marsh plant root density, resulting in differences in sediment mixing rates. Studies that acknowledge differences in behaviour or bioturbation rates within a species across differing sediment types and physical conditions have only recently been reported (Biles et al. 2003, Escapa et al. 2008, Sassa \& Watabe 2008).

In the present study we assessed the functional role of the burrow-building, surface deposit-feeding grapsid crab Austrohelice crassa (cf. Helice crassa, Dana 1852), a ubiquitous component of New Zealand's estuaries. These highly mobile organisms, which grow up to $2.3 \mathrm{~cm}$ carapace width (CW), are often found in high densities (up to $462 \mathrm{~m}^{-2}$; Jones \& Simons 1983) in the mid to high shore region. They inhabit a wide spectrum of sediment types from silt to coarse sand with reported burrow depths of up to $60 \mathrm{~cm}$ (Nye 1977, Morrisey et al. 1999). Despite being recognised as important bioturbators in many New Zealand estuaries, sediment reworking rates have not been quantified in previous studies (Morrisey et al. 1999, Williamson et al. 1999, Gibbs et al. 2001, Norkko et al. 2002). As grapsids do not secrete reactive mucous or reinforce their burrows like burrowing shrimp (Nickell \& Atkinson 1995, Kristensen \& Kostka 2005), differences in burrow permanency and morphology (a proxy for burrow wall surface area) are likely to occur with changes in sediment grain size. If burrow permanency is distinctly different in cohesive or non-cohesive sediments, this will alter the frequency that a crab rebuilds its burrow, in turn altering the rate at which sediment is mixed. Similarly, if burrow morphology varies as a function of sediment type, differences in burrow wall surface area among habitats may drive changes in ecosystem processes such as nutrient exchange. By assessing the differences in burrowing behaviour and sediment reworking capacity of $A$. crassa, we aimed to elucidate its primary bioturbational role across habitats. 
To quantify possible shifts in Austrohelice crassa's contribution to ecosystem functioning through bioturbation, we constructed and parameterised a simple sediment reworking model in different habitat types. Specifically, as a function of sediment type (cohesive mud to fine sand), we determined 4 terms to calculate sediment mixing rates: (1) burrow and crab density; (2) burrow morphology and depth-related changes in the surface area and volume of these structures; (3) burrow permanency; and (4) sediment excavation rates during burrow maintenance. Burrow permanency provided the dynamic element of this model. Similar to Gardner et al.'s (1987) regeneration model, our assumption was that a new burrow was built for each one infilled. Burrow morphology measurements not only quantified the amount of sediment excavated during burrow formation, but also enabled calculation of the increase in sediment-water interface, allowing the primary bioturbatory function of $A$. crassa in each sediment environment to be determined.

\section{MATERIALS AND METHODS}

Four interlinking observational studies were conducted to determine the terms required to calculate sediment reworking rates in 3 different sediment environments (Fig. 1): fine sand (PE2), muddy sand (PA4) and mud (PA1). Burrow permanency observations were limited to these 3 locations due to logistical constraints; however, patterns of crab abundance and burrow morphology were first investigated at a larger number of sampling stations to ensure that the 3 more

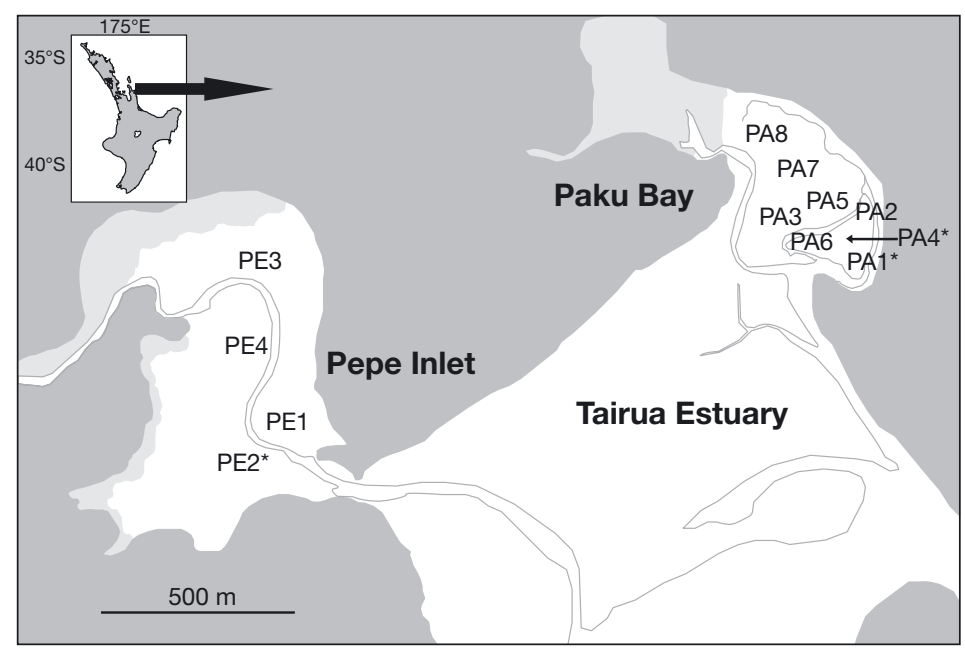

Fig. 1. Inset: North Island, New Zealand. Arrow: study location at Tairua Estuary, Coromandel Peninsula. Main figure: proximity of the 2 bays and sampling stations. Light shaded areas: mangroves and fringing vegetation. Grey line: channel edges at low tide. ${ }^{*}$ : stations used to calculate sediment reworking rates intensely studied locations typified the environments inhabited by Austrohelice crassa. This wider-scale sampling also provided insight into the drivers of the observed crab-sediment interactions.

Study sites. Studies were conducted in 2 sheltered embayments in Tairua Estuary, North Island, New Zealand (Fig. 1). The 2 sites, Paku Bay and Pepe Inlet, were selected for their high abundance of Austrohelice crassa, similar inundation periods and tidal heights. Due to the close proximity of the 2 embayments and the range of $A$. crassa habitats, sampling stations across both locations were treated as a continuous gradient of sedimentary variables. Sampling effort reflected the heterogeneity of each bay with 4 sampling stations in the fine sands of Pepe Inlet (PE1-PE4) and 8 in Paku Bay: 2 in silt-clay (PA1 \& 2), 2 in muddy sand (PA3 \& 4), 2 in fine sand (PA5 \& 6) and 2 in medium sand with a gravel top layer (PA7 \& 8). Sampling stations were not equidistant (most were $\geq 100 \mathrm{~m}$ apart) and reflected spatial distributions in sediment properties. The greatest distance between stations situated at the far sides of each bay (PA1-PA8 and PE2-PE3) was $\sim 550 \mathrm{~m}$, and the closest stations between bays (PE3 \& PA3) were $\sim 1 \mathrm{~km}$ apart. All sampling was undertaken during the late spring (November) and summer (February) 2008 on spring tides.

Sediment parameters and crab abundance. At each station, three $0.25 \mathrm{~m}^{2}$ quadrats were placed on the sediment surface and all visible burrow openings were counted, noting the number of burrows with diameters $>10 \mathrm{~mm}$. Samples for grain size, chlorophyll a (chl a) and total organic matter (TOM) content were then collected at random from inside each quadrat using a $2.8 \times 1 \mathrm{~cm}$ (diameter $\times$ length) corer. Three replicate cores per quadrat were collected and pooled for each analysis. The remaining sediment in each quadrat was excavated to a depth of $20 \mathrm{~cm}$, visually checking that no crabs were lost in the process, and sieved on a $1 \mathrm{~mm}$ mesh screen. Crabs and other large macrofauna were preserved in isopropyl alcohol for later identification and enumeration. Crab carapace width (CW) was measured to the nearest $0.1 \mathrm{~mm}$ using digital callipers and the sex of each mature crab (i.e. $>5 \mathrm{~mm}$ CW, below which gender was indeterminate) was recorded.

Burrow morphology. A $1 \mathrm{~m}^{2}$ quadrat was arbitrarily positioned at each station with a $0.25 \mathrm{~m}^{2}$ quadrat placed at random within it. This smaller quadrat enabled a subset of the total burrow number to be counted and compared to previous burrow surveys at each station, enabling correlative patterns in burrow 
morphology and density to be elucidated. At each station, 10 burrows were randomly selected from a numbered grid of 25 cells $(20 \times 20 \mathrm{~cm})$ within the $1 \mathrm{~m}^{2}$ quadrat. Only one burrow per cell was cast, and prior to pouring the resin, each burrow opening was measured across both axes. Burrow casts were not collected from PA8, as this area had been subject to disturbance, leaving very few visible burrows present. A PVC collar (either 6 or $12 \mathrm{~cm}$ in diameter depending on the size of the burrow opening) was placed on the sediment surface, separating the burrow opening from its surroundings. Catalysed polyester resin (Norski Products) was poured into each burrow until flush with the sediment surface. Resin casts were left in situ for $24 \mathrm{~h}$ to harden before being excavated from the sediment by hand. Casts were left to air dry for an additional $7 \mathrm{~d}$ before being thoroughly cleaned of residual sediment with a brush. Casts were analysed morphometrically by dividing each burrow into its component shapes (e.g. cone-shaped burrow entrance, cylindrical burrow shaft, etc.). Surface area and volume were calculated from the linear dimensions of each component shape and then summed. Burrow length was calculated similarly. Maximum depth was measured directly from the level of the sediment surface to the deepest point of the cast and the number of surface openings and overall burrow shape, irrespective of size, was recorded.

Eight different and distinct burrow forms were categorised across the 11 stations (Fig. 2). These ranged from the simple cone-, i- and j-shaped burrows to complex structures known as 'inverted y' and 'branching'. Some burrows (y- and u-shaped) were classified by their dual surface openings. Large matrices of interconnecting burrows were also observed in association with burrowing shrimp species. These burrows were described as 'complex'.

Burrow permanency. Three stations from the original 12 were established for monitoring burrow permanency from which the rate of decay could be estimated. Each station had adult Austrohelice crassa densities $>10$ ind $0.25 \mathrm{~m}^{-2}$ and best represented 3 distinct habitats found within the sediment gradient (see Fig. 3a): mud (PA1), muddy sand (PA4) and fine clean sand (PE2). Five $0.25 \mathrm{~m}^{2}$ plots marked at the corners with pegs (1 cm diameter) were created along a transect parallel to the incoming tide at lower mid-tide level. In each plot, 10 burrows with an aperture
$>10 \mathrm{~mm}$ were measured and individually marked using numbered thin wire flags. On each visit, the presence/absence of flagged burrows was recorded and the total number of burrows ( $>10 \mathrm{~mm}$ diameter) within each quadrat was counted to look for changes in burrow density over time. All 15 quadrats were visited daily for $1 \mathrm{wk}$, weekly for $1 \mathrm{mo}$ and monthly for 2 mo.

Burrow maintenance. In unconsolidated sandy sediments, Austrohelice crassa clear their burrows just after the sand flat is exposed. Sediments are pelletized and removed from the burrow by the occupant crab. These pellets are usually dark in colour, relative to ambient surface sediments, and easily distinguished from feeding pellets. In muddy, cohesive sediments, signs of burrow maintenance were not as apparent, as lower bedload transport appears to reduce the frequency of burrow clearance (H. R. Needham pers. obs.). Similarly, in the coarsest-grained stations, where
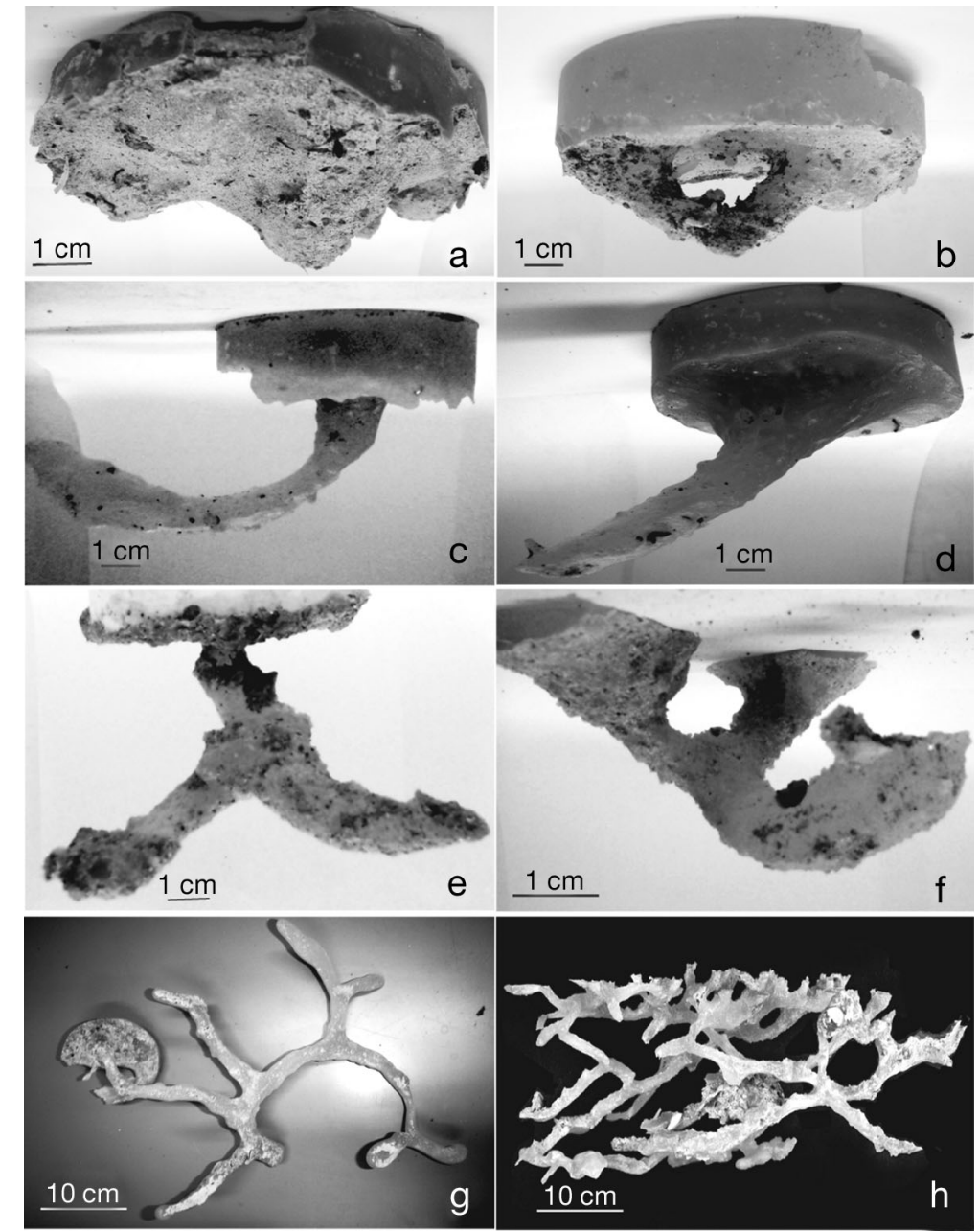

Fig. 2. Casts of the 8 burrow forms found across the 11 stations. Burrow forms were classified as: (a) cone, (b) u, (c) j, (d) i, (e) inverted y, (f) y, (g) branching, and $(\mathrm{h})$ complex (formed with other species; in this instance, alpheid shrimp) 
a gravel top layer was present, pellets were not distinct, making measurements of burrow maintenance only possible in fine sand.

To measure the amount of sediment cleared from a burrow as the tide receded, six $0.25 \mathrm{~m}^{2}$ plots were created $5 \mathrm{~m}$ apart on a transect running from the shore to the channel edge (as elevation changes were minimal) at PE1 (Fig. 1). Each plot was positioned and marked with corner pegs (1 cm diameter) as soon as the tide uncovered the area. Sampling began $1 \mathrm{~h}$ after each plot was exposed to air, as burrow clearance by Austrohelice crassa generally starts at this time. An 8 min lag between dewatering of each plot meant all sediment collection could be completed on 1 tide. To commence sampling, all burrows with excavated sediment surrounding the opening were individually marked with numbered fine wire flags. Each burrow opening was measured across both axes to the nearest millimetre and the pellets were removed using a small steel spatula. Marked burrows were repeatedly sampled on an hourly basis until no further excavate was found ( 3 h post-exposure). Transect surveys were repeated on 3 consecutive days with plots placed parallel to, but spaced $5 \mathrm{~m}$ away from, the previous day's site. The excavated sediment was frozen at $-20^{\circ} \mathrm{C}$ until analysis for dry weight (DW), TOM and grain size was conducted.

Sediment analyses. TOM was determined through loss on ignition from dried sediments $\left(105^{\circ} \mathrm{C}\right.$ for $\left.24 \mathrm{~h}\right)$, after combustion for $5.5 \mathrm{~h}$ at $550^{\circ} \mathrm{C}$ (Dean 1974). Sediments for particle size analysis were treated with $10 \%$ hydrogen peroxide to remove organic matter (Day 1965) before analysis on a Malvern mastersizer-S (300 FR lens) to determine grain size fractions in the range of 0.05 to $2000 \mu \mathrm{m}$. Chl a ( $\left.\mu \mathrm{g} \mathrm{g}^{-1} \mathrm{DW}\right)$ was determined from freeze-dried sediment and extracted in $90 \%$ acetone for $24 \mathrm{~h}$ before centrifugation; concentrations were determined fluorometrically, on a Turner 10-AU fluorometer, using an acidification step to separate phaeophytin concentration from that of photosynthetic pigments (Arar \& Collins 1997).

Data analysis. Correlation coefficients (Pearson's r) were calculated to determine relationships between crab and burrow density and sediment properties across all 12 stations. Correlation-based principal component analysis (PCA) was used to visualise the sediment gradient based on the measured sediment variables. All axes were normalised to enable comparison of Euclidean distances between sample points, irrespective of the measurement units. Highly correlated variables were excluded when $r>0.8$. From this PCA, 3 distinct stations were selected for the estimation of sediment reworking rates. To assess differences in crab size between stations, a Kruskal-Wallis test was conducted with post hoc multiple comparisons tests, as parametric ANOVA assumptions were not met. The number of burrows remaining through time were used to estimate burrow decay rates $\left(k \mathrm{~d}^{-1}\right)$ by fitting an exponential decay model $\left(\mathrm{Y}=\mathrm{Y}_{0} \mathrm{e}^{-k t}\right)$ using non-linear least squares regression with the LevenbergMarquardt algorithm as the measure of estimation (Levenberg 1944). The decay constant of each sediment type was used to calculate the mean burrow permanency $\left(B_{\mathrm{p}}=1 / \mathrm{k}\right)$ in each of the 3 locations. Oneway ANOVA was used to test if burrow maintenance rates differed as a function of shore position. Type III sums of squares were used to perform this analysis due to the differing burrow number in each quadrat. Simple linear regression was used to establish if relationships between the DW of sediment expelled and burrow aperture existed. All analyses were computed using Statistica software (Stat Soft, release 8) apart from PCA where Primer V6 (Primer-E) was used.

Model calculations. To calculate sediment reworking rates in the mud (PA1), muddy sand (PA4) and sand (PE2), resin cast data from each location were used to determine the average amount of sediment exhumed when a burrow is first created ( $B_{g i} g$ DW) using the formula:

$$
B_{\mathrm{g}}=V \rho
$$

where $V$ is the mean volume of adult burrows cast $\left(\mathrm{cm}^{3}\right)$ in each station and $\rho$ is the salt-corrected dry bulk density of the sediment $\left(\mathrm{g} \mathrm{cm}^{-3}\right)$ from that location. Sediment reworking rates $\left(S R_{;} \mathrm{g} \mathrm{DW} \mathrm{m}^{-2} \mathrm{SLM}^{-1}\right)$ were then calculated for each of the 3 sediment types as follows:

$$
S R=B_{\mathrm{g}} C_{\mathrm{n}}\left(\mathrm{SLM} / B_{\mathrm{p}}\right)
$$

where SLM (summer lunar month) is a constant $28 \mathrm{~d}$, $C_{\mathrm{n}}$ is the mean crab density (ind. $\mathrm{m}^{-2}$ ) and $B_{\mathrm{p}}$ is the mean crab burrow permanency (d) in each location. Our equation, like that of Katz (1980) and Gardner et al. (1987), assumes that the rates of burrow construction and collapse are equal, i.e. a crab makes a new burrow each time an old burrow collapses. For the sand site only, the mean amount of sediment excavated during burrow maintenance $\left(B M ; \mathrm{g} \mathrm{DW} \mathrm{m} \mathrm{m}^{-2}\right.$ $\mathrm{SLM}^{-1}$ ) was also calculated:

$$
B M=C_{\mathrm{n}}\left(S_{\mathrm{e}} \mathrm{Ti}\right)
$$

where $S_{\mathrm{e}}$ is the mean amount of sediment excavated ( $\mathrm{g}$ DW $\mathrm{crab}^{-1}$ low tide ${ }^{-1}$ ) and $\mathrm{Ti}$ is the number of tidal exposures per lunar month (a constant 56, 2 exposures per day for $28 \mathrm{~d}$ ). Therefore, total sediment reworking (TSR; $\mathrm{g} \mathrm{DW} \mathrm{m}^{-2} \mathrm{SLM}^{-1}$ ) can be summarised as:

$$
T S R=S R+B M
$$

The increase in sediment surface area created by Austrohelice crassa burrows was estimated from resin casts of adult crab burrows found in the 3 locations 
$(\mathrm{n}=8)$. Burrow density information from each location enabled estimations of the total increase in sediment surface area through A. crassa bioturbation. Similarly, total burrow volume of each area, based on burrow density, was also calculated. Upper and lower confidence intervals (95\%) around the mean were carried forward through each step of the calculation to gain an estimate of associated error.

\section{RESULTS}

\section{Sediment surface properties}

Sites spanned the range from fine silt-clay (mean grain size $=22 \mu \mathrm{m})$ at PA1 to medium sand with a gravel top layer $($ mean grain size $=257 \mu \mathrm{m})$ at PA8 (Table 1). The muddiest site, PA1, exhibited the greatest sediment TOM, silt-clay and chl a content. Silt-clay content ranged from 77.3 to $10.4 \%$ across the sediment gradient, whilst TOM content ranged from $6 \%$ in fine sediments down to $2.3 \%$ in sand. $\mathrm{Chl}$ a concentration varied between stations from 18.3 to $8.6 \mu \mathrm{m} \mathrm{gW}^{-1}$, with the highest concentration in the muddiest and lowest concentration in the coarsest sediments. Sediment properties showed strong, significant correlations with each other, indicating predictable relationships between parameters across the spectrum of sites (Table 2). A 2-dimensional correlation-based PCA ordination of surface sediment properties showed that $65.5 \%$ of the variation among sites was explained by median grain size and silt-clay content on PC1 (eigenvalue 3.93), with a further $24.7 \%$ variation attributable to the biologi- cally derived pigments (chl a and phaeophytin) on PC2 (eigenvalue 1.48; Fig. 3a). This PCA also visually highlights the spread of the 3 stations chosen for the calculation of sediment reworking rates driven mainly by differences on axis PC1.

\section{Abundance and distribution}

Austrohelice crassa populations showed a similar range in CW across 11 of the 12 sites, with a mean $( \pm \mathrm{SD}) \mathrm{CW}$ ranging from $5.8 \pm 2.3 \mathrm{~mm}$ at PA5 to $8.6 \pm$ $3.7 \mathrm{~mm}$ at PE3 (Fig. 4a). PA3 was the only station where mean crab CW $(9.8 \pm 2.7 \mathrm{~mm})$ was greater than at any of the other sampled locations (KruskalWallis multiple comparisons test, all $\mathrm{p}<0.018$ ). The stations with the greatest crab abundance were PA1, PA4 and PA7, with a peak density of $55.3 \pm 7.1$ ind. $^{-1}$ $0.25 \mathrm{~m}^{-2}$ at PA4 (Fig. 4b). These 3 stations all had high silt-clay content, despite differing in other sediment properties (Table 1). Burrow density $\left(0.25 \mathrm{~m}^{-2}\right)$ ranged from $295 \pm 44.17$ at PA1 to $26 \pm 2.65$ at PE1 (Fig. 4c). Differences in burrow:crab ratio (Fig. 4d) were observed across the sediment gradient, with the greatest number of burrows per crab occurring at the muddiest station, PA1 $(5.7 \pm 0.7)$, with the closest association being $1.4 \pm 0.3$ burrows per crab in fine clean sand (PE2).

The crab population was split into 2 categories, juveniles $(<5 \mathrm{~mm} \mathrm{CW})$ and adults $(>5 \mathrm{~mm} \mathrm{CW})$, which were both shown to correlate significantly with burrow density $(\mathrm{p}<0.001$; Table 2$)$. Strong correlations $(\mathrm{p}<$ 0.005 ) with percentage silt-clay, porosity and TOM over that of grain size $(p=0.042)$ were also apparent.

Table 1. Surface sediment properties across the 12 stations sampled in Tairua Estuary. Values represent averages of the 0-1 $\mathrm{cm}$ layer in all but granulometric samples, which were taken to a depth of $2 \mathrm{~cm}$. SD in parentheses $(\mathrm{n}=3)$. Sites are ordered according to mean grain size, from finest (PA1) to coarsest (PA7). TOM: total organic matter; chl a: sediment chlorophyll $a$; phaeo: sediment phaeopigment

\begin{tabular}{|c|c|c|c|c|c|c|c|}
\hline Station & $\begin{array}{c}\text { TOM } \\
(\%)\end{array}$ & $\begin{array}{c}\text { Chl a } \\
\left(\mu \mathrm{g} \mathrm{g}^{-1}\right)\end{array}$ & $\begin{array}{l}\text { Phaeo } \\
\left(\mu g^{-1}\right)\end{array}$ & $\begin{array}{l}\text { Median grain size } \\
(\mu \mathrm{m})\end{array}$ & $\begin{array}{l}\text { Silt-clay } \\
(\%)\end{array}$ & Porosity & $\begin{array}{c}\text { Water content } \\
(\%)\end{array}$ \\
\hline $\mathrm{PA} 1^{\mathrm{a}}$ & $6.0(0.13)$ & $18.3(0.9)$ & $12.6(2.4)$ & $22(3)$ & $77.3(3.8)$ & $0.66(0.01)$ & $76.3(4.0)$ \\
\hline PA2 & $4.2(0.70)$ & $13.7(6.4)$ & $17.1(12.0)$ & $94(62)$ & $53.1(24.3)$ & $0.55(0.03)$ & $47.8(6.0)$ \\
\hline PA3 & $4.3(0.46)$ & $13.2(2.5)$ & $13.2(2.0)$ & $94(47)$ & $42.6(19.1)$ & $0.57(0.00)$ & $50.6(0.4)$ \\
\hline $\mathrm{PA} 4^{\mathrm{a}}$ & $4.4(0.41)$ & $17.1(1.6)$ & $17.1(1.5)$ & $96(43)$ & $42.1(9.8)$ & $0.58(0.01)$ & $53.4(2.6)$ \\
\hline PE3 & $3.9(1.03)$ & $14.9(1.3)$ & $19.2(3.8)$ & $162(29)$ & $19.9(6.1)$ & $0.49(0.04)$ & $31.7(5.4)$ \\
\hline PA5 & $3.8(0.12)$ & $15.7(2.6)$ & $15.7(0.6)$ & $168(3)$ & $23.1(0.7)$ & $0.44(0.02)$ & $30.0(2.2)$ \\
\hline $\mathrm{PE} 2^{\mathrm{a}}$ & $2.3(0.03)$ & $14.4(2.9)$ & $19.2(3.8)$ & 168 (16) & $19.3(3.3)$ & $0.39(0.01)$ & $25.2(0.9)$ \\
\hline PA6 & $3.0(0.16)$ & $11.5(1.0)$ & $8.8(5.3)$ & $170(9)$ & $21.4(9.8)$ & $0.47(0.01)$ & $34.4(1.4)$ \\
\hline PE4 & $2.3(0.33)$ & $10.7(4.3)$ & $15.6(4.0)$ & $171(34)$ & 26.1 (14.4) & $0.41(0.04)$ & $27.4(5.0)$ \\
\hline PE1 & $2.7(0.35)$ & $15.7(5.5)$ & $28.2(24.4)$ & $174(7)$ & $10.4(0.4)$ & $0.42(0.03)$ & $27.8(3.2)$ \\
\hline PA7 & $2.9(0.23)$ & $11.9(2.3)$ & $6.7(1.3)$ & $256(22)$ & $40.7(1.1)$ & $0.45(0.02)$ & $31.1(2.0)$ \\
\hline PA8 & $2.7(0.45)$ & $8.6(0.7)$ & $8.6(0.8)$ & 257 (39) & $23.1(5.54)$ & $0.45(0.07)$ & $32.1(0.8)$ \\
\hline
\end{tabular}


Table 2. Pearson's r correlation coefficients calculated between Austrohelice crassa densities, burrow densities and surface sediment properties from each of the 12 stations across the sediment gradient. Juvenile: total $<5 \mathrm{~mm}$ CW; Adult: total $>5 \mathrm{~mm}$ CW; CW: carapace width; TOM: total organic matter; chl a: sediment chlorophyll $a_{\text {; }}$ phaeo: sediment phaeopigment; DW: dry weight. Significant values are in bold. ${ }^{*}: \mathrm{p}=<0.05^{* *}: \mathrm{p}=<0.01{ }^{* * *}: \mathrm{p}=<0.001$

\begin{tabular}{|c|c|c|c|c|c|c|c|c|c|}
\hline & $\begin{array}{c}\text { Burrow } \\
\text { density } \\
\left(0.25 \mathrm{~m}^{-2}\right)\end{array}$ & $\begin{array}{l}\text { Juvenile } \\
\text { A. crassa } \\
\text { CW }\end{array}$ & $\begin{array}{l}\text { Adult } \\
\text { A. crassa } \\
\text { CW }\end{array}$ & $\begin{array}{c}\text { TOM } \\
(\%)\end{array}$ & $\begin{array}{c}\text { Median } \\
\text { grain size } \\
(\mu \mathrm{m})\end{array}$ & $\begin{array}{c}\text { Silt-clay } \\
(\%)\end{array}$ & $\begin{array}{c}\text { Chl a } \\
\left(\mu \mathrm{g} \mathrm{g}^{-1}\right. \\
\mathrm{DW})\end{array}$ & $\begin{array}{c}\text { Phaeo } \\
\left(\mu g g^{-1}\right. \\
\text { DW })\end{array}$ & Porosity \\
\hline Burrow density $\left(0.25 \mathrm{~m}^{-2}\right)$ & 1 & & & & & & & & \\
\hline Juvenile $A$. crassa CW & $0.66^{* * *}$ & 1 & & & & & & & \\
\hline Adult A. crassa CW & $0.67^{* * *}$ & $0.81^{* * *}$ & 1 & & & & & & \\
\hline TOM (\%) & $0.79^{* * *}$ & $0.43^{* *}$ & $0.53^{* *}$ & 1 & & & & & \\
\hline Median grain size $(\mu \mathrm{m})$ & $-0.62^{* * *}$ & -0.19 & $-0.36^{*}$ & $-0.75^{* * *}$ & 1 & & & & \\
\hline Silt-clay (\%) & $0.84^{* * *}$ & $0.57^{* * *}$ & $0.70^{* * *}$ & $0.78^{* * *}$ & $-0.70^{* * *}$ & 1 & & & \\
\hline Chl a $\left(\mu g g^{-1} \mathrm{DW}\right)$ & $0.41^{*}$ & 0.21 & 0.21 & $0.51^{* *}$ & $-0.52^{* *}$ & 0.31 & 1 & & \\
\hline Phaeo $\left(\mu g g^{-1} \mathrm{DW}\right)$ & -0.09 & -0.09 & -0.2 & -0.04 & -0.16 & -0.2 & 0.12 & 1 & \\
\hline Porosity & $0.75^{* * *}$ & $0.52^{* *}$ & $0.50^{* * *}$ & $0.80^{* * *}$ & $-0.62^{* * *}$ & $0.68^{* * *}$ & $0.41^{*}$ & -0.16 & 1 \\
\hline
\end{tabular}

Overall, burrow and adult crab density displayed similar relationships to measured sediment properties, the only exception being chl $a$, which correlated with burrow density only. The abundance of juvenile crabs followed that of the adult population in all but their association with mean grain size.
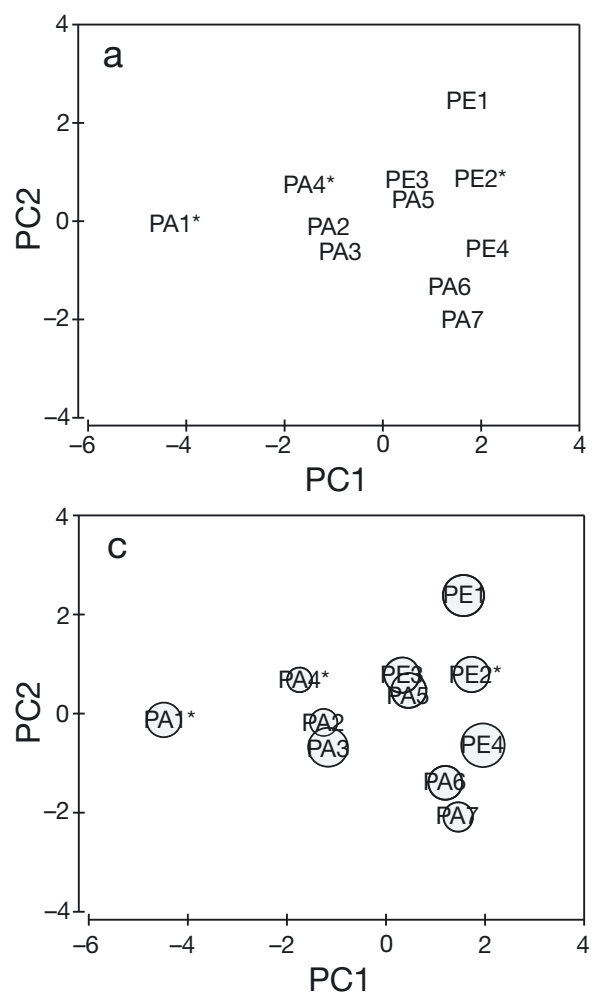

\section{Burrow morphology}

The most common burrow forms were $\mathrm{j}$ - and ishaped, with branching and inverted y forms also occurring across the sediment gradient, although more frequently in fine to medium sand (Fig. 5). No burrow
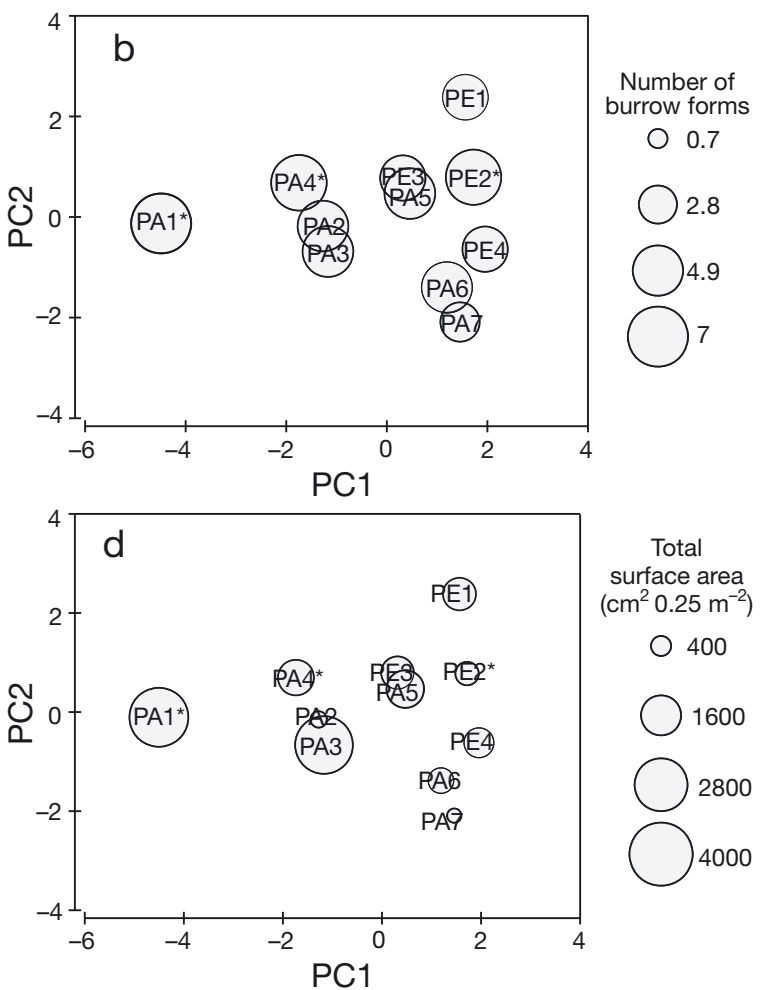

Fig. 3. Two-dimensional correlation-based principal component analysis (PCA) ordination of the surface sediment properties across the sediment gradient. (a) PC1 and PC2 account for $90.2 \%$ of the total variance across the 11 stations sampled. Increasing values on PC1 correlate positively with grain size and negatively with silt-clay content (65.5\%, eigenvalue 3.93$)$. PC2 values positively correlate with sediment pigments $(24.7 \%$, eigenvalue 1.48$)$. Overlain bubble plots display changes in the (b) number of burrow forms present, (c) mean burrow surface area and (d) total burrow surface area at each station. ${ }^{*}$ : stations used to calculate sediment reworking rates 

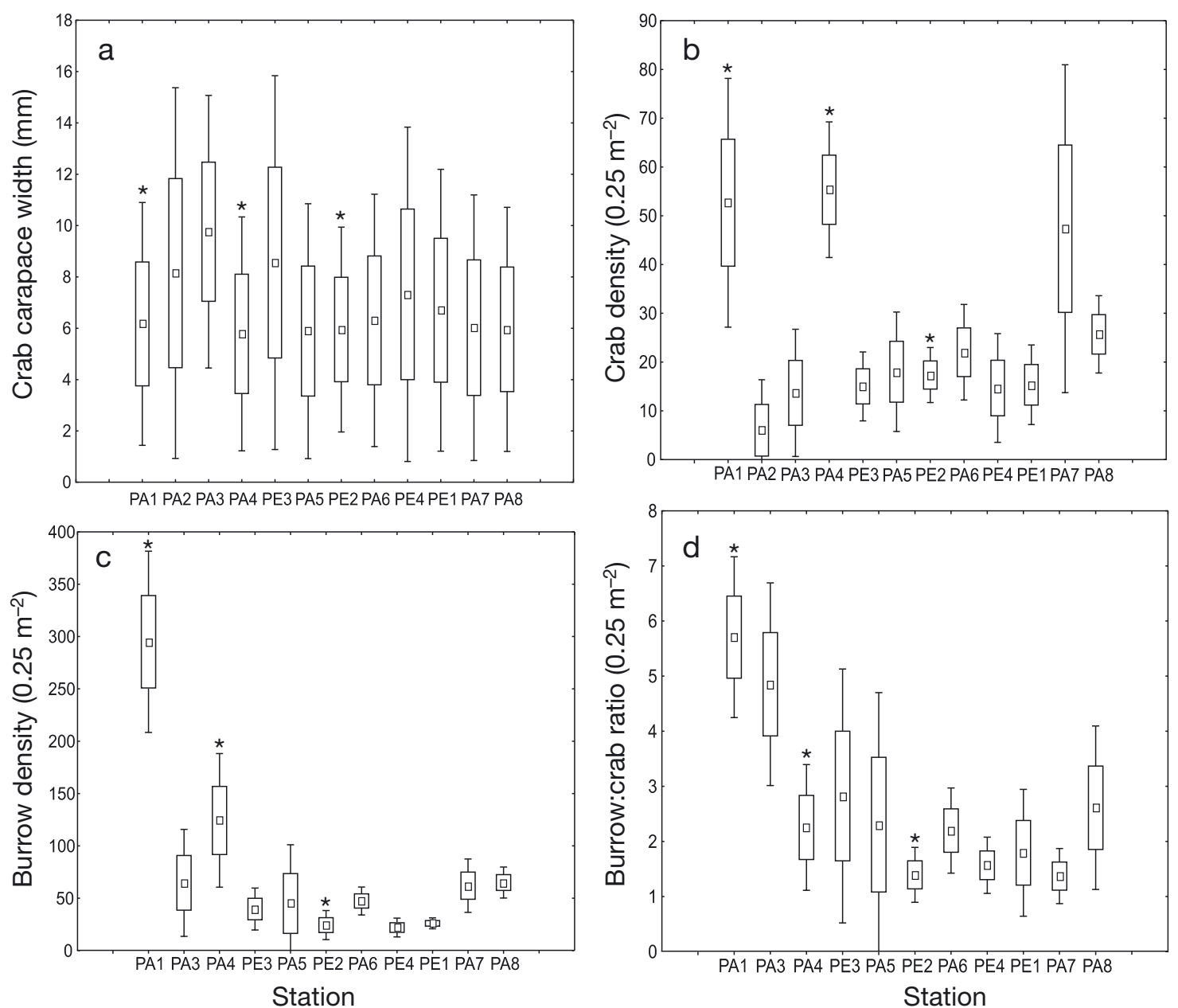

Fig. 4. Box and whisker plots of (a) Austrohelice crassa population size structure, (b) mean crab density, (c) burrow density and (d) burrow:crab ratio at each station. Stations are ordered according to mean grain size from finest (PA1) to coarsest (PA7). *: stations used to calculate sediment reworking rates. The central box indicates the mean, the surrounding box represents $\pm 1 \mathrm{SD}$ and the whiskers denote the upper and lower 95\% CI. Stn PA2 was removed from panels (c) and (d) due to the high density of Alpheus sp. burrows, which were indistinguishable from Austrohelice crassa burrows at the sediment surface

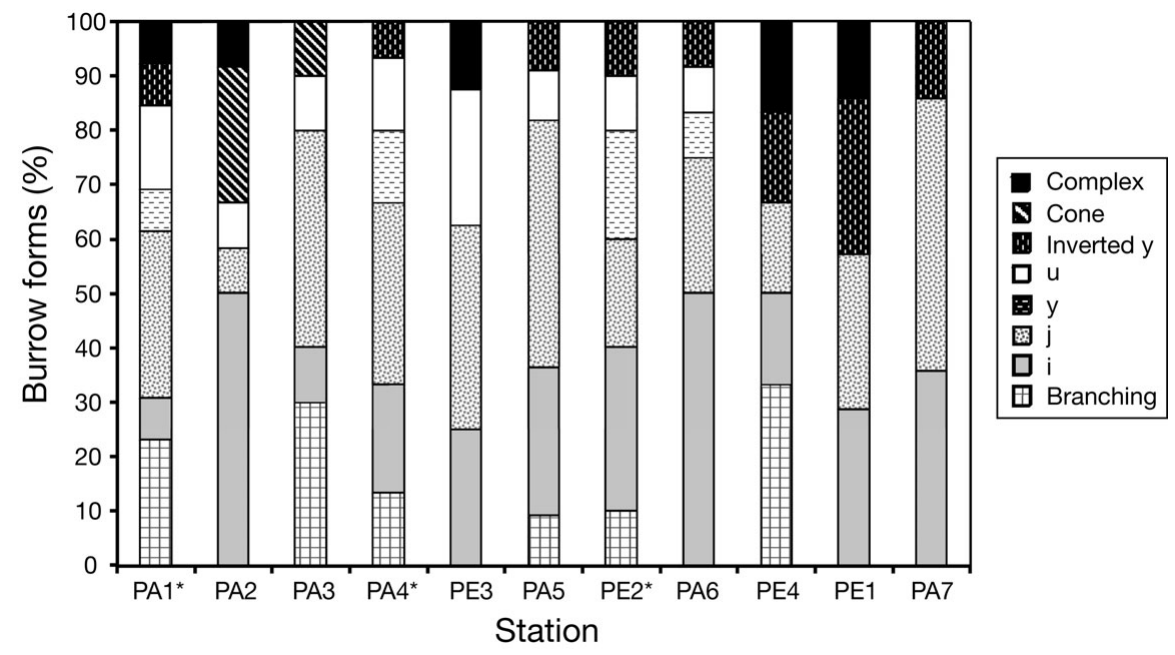

Fig. 5. Percentage of differing burrow forms at each of the 11 stations. Stations are ordered according to mean grain size, with PA1 the finest and PA7 the coarsest. Burrows with more than one surface opening were counted as a single burrow structure, including 'complex' multi-species casts. ${ }^{*}$ : stations used to calculate sediment reworking rates 
forms with multiple entrances $(\mathrm{y}, \mathrm{u})$ were observed in the 3 coarsest sediments (PE4, PE1 and PA7), and cone-shaped burrows were cast at Stns PA2 and PA3 only. 'Complex' casts of mixed species found at the muddiest stations (PA1 and PA2) were created in conjunction with alpheid shrimp, whilst those at PE1, PE3 and PE4 were morphologically typical of callianassid species (Nickell \& Atkinson 1995). These burrow matrices were excluded from all further analyses as it was impossible to disentangle the effects of the various crustacean burrowers.

Burrow diversity (i.e. the number of burrow forms cast at each sampling station) did not display predictable patterns across the sediment gradient despite the greatest number of burrow forms being found at the muddiest station (7, PA1) and the fewest at the coarsest station (3, PA7; Fig. 3b). Patterns in mean burrow surface area (Fig. 3c) were also inconsistent across the sediment gradient and did not show significant correlations with any of the measured sediment parameters $(|r|<0.55, p>0.08)$. As mean burrow surface area was highly correlated with mean burrow volume, length and depth ( $\mathrm{r}>0.83$, $\mathrm{p}<0.001$ ), this pattern was similar for all burrow metrics. However, when scaled with burrow density, total surface area and, hence, other burrow metrics, showed a tendency to decrease with increasing grain size $(\mathrm{r}=$ $-0.71, \mathrm{p}=0.014 ;$ Fig. 3d).

\section{Burrow permanency}

The permanency of burrows at each station showed distinct differences across the 3 sediment types (Fig. 6). After $6 \mathrm{~d}$ of observations, all marked burrows at the sand station (PE2) had infilled. This differed greatly to the other 2 stations, which after 2 mo of observations had $8 \pm 13 \%$ (muddy sand, PA4) and $22.5 \pm 1.26 \%$ (mud, PA1) of their marked burrows remaining. No major fluctuations in total burrow number per station were witnessed during the observational period, indicating a steady state in the rate of burrow formation and decay. The fitted exponential decay models were all highly significant $\left(\mathrm{r}^{2}>0.89, \mathrm{p}<0.0001\right.$; Fig. 5), with the decay constant $(k)$ differing by an order of magnitude between sand and mud. Sand showed the fastest rate of decline $\left(k=0.72,95 \% \mathrm{CI}=0.63\right.$ to $\left.0.81 \mathrm{~d}^{-1}\right)$ and mud the slowest $(k=0.039,95 \% \mathrm{CI}=0.031$ to 0.046 $\mathrm{d}^{-1}$ ), with muddy sand displaying more similarities with mud $\left(k=0.092,95 \% \mathrm{CI}=0.068\right.$ to $\left.0.117 \mathrm{~d}^{-1}\right)$. The mean burrow permanency $(1 / k)$ indicated a burrow would last on average $25.7 \mathrm{~d}$ in mud, $10.8 \mathrm{~d}$ at the intermediate site and only $1.4 \mathrm{~d}$ in sand.

\section{Sediment evacuation during burrow maintenance}

The amount of sediment excavated during burrow maintenance at low tide was highly variable (Fig. 7). The amount of sediment excavated ( $g$ DW burrow ${ }^{-1}$ ) did not differ with shore position across the 3 transects $(F=1.78$, df $=5, \mathrm{p}=0.12)$, so all data were pooled. Burrow aperture size was related to the amount of sediment excavated across all 141 burrows $\left(\mathrm{r}^{2}=0.25 \mathrm{p}<\right.$ 0.001 ; Fig. 7). On average, this material contained $2.5 \pm$ $0.6 \%$ TOM, a fractionally lower value than that of the surface sediment of the surrounding area $(2.8 \pm 0.9 \%)$. Mean grain size of the pelletized material did not differ from that of the sediment surface $(170 \pm 24 \mu \mathrm{m})$.

\section{Differences in burrow surface area and sediment reworking rates with grain size}

Total burrow wall surface area was estimated to average $14180 \mathrm{~cm}^{2} \mathrm{~m}^{-2}$ in mud, almost 3 times greater than the $4968 \mathrm{~cm}^{2} \mathrm{~m}^{-2}$ estimated for the muddy sand site and 6.5 times greater than the $2180 \mathrm{~cm}^{2} \mathrm{~m}^{-2}$ in fine sand (Table 3 ). This equates to a mean increase in the sediment-water interface of $142 \%$ (mud), $50 \%$ (muddy sand) and $22 \%$ (sand) through the presence of Austrohelice crassa burrows. Total burrow volume displayed similar trends to that of increased sedi- 


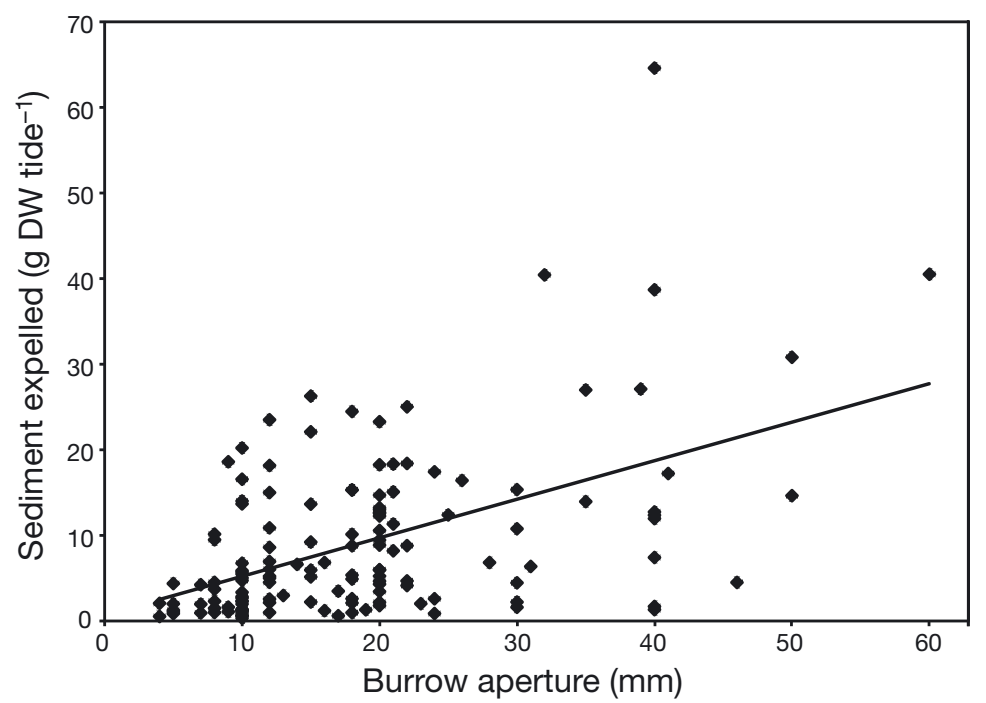

Fig. 7. Relationship between burrow aperture diameter and the amount of sediment brought to the surface during burrow maintenance $\left(\mathrm{r}^{2}=0.25\right.$, $\mathrm{p}=<0.001)$. All samples were collected from transects near Stn PE1

Table 3). These estimates were converted to monthly percentages (using the median burrow depth to calculate the volume of sediment available to crabs) to enable comparisons across stations and times. On average, $7.4 \%$ of the sediment volume available to Austrohelice crassa was reworked monthly in summer at both the mud and muddy sand stations. Sand proved much more dynamic, with almost $82 \%$ of the sediment volume being reworked per month. The greatest variance in burrow reworking estimates was evident at the sandy station (95\% $\mathrm{CI}=9.8$ to $244 \%$ ). The lower estimate for sand was still greater than the mean sediment reworking rate of both other sediment types, indicating functionally important differences in rates of sediment mixing.

Burrow maintenance also contributed to sediment reworking rates in sand, and the average amount of sediment excavated for ment-water interface: total burrow volume was greatest in mud $\left(4635 \mathrm{~cm}^{3} \mathrm{~m}^{-2}\right)$, which was 3.8 times greater than the $1373 \mathrm{~cm}^{3} \mathrm{~m}^{-2}$ at the muddy sand site and 4.7 times greater than the $997 \mathrm{~cm}^{3} \mathrm{~m}^{-2}$ in sand (Table 3).

Rates of sediment reworking were very similar in both mud and muddy sand locations (about $3.1 \mathrm{~kg}$ DW sediment $\mathrm{m}^{-2} \mathrm{SLM}^{-1}$ ), whilst reworking in sand was much greater $\left(47.2 \mathrm{~kg}\right.$ DW sediment $\mathrm{m}^{-2} \mathrm{SLM}^{-1}$; maintenance purposes from adult burrows was incorporated into total sediment reworking rates (Table 3). It was assumed that crabs showed similar circatidal rhythms, excavating equivalent amounts of sediment irrespective of the time of low tide. Including these extra sediment expulsions increased the upper estimate of sediment reworking to $333 \%$, the mean to $129 \%$ and the lower estimate to $24 \%$, generating a total mean sediment reworking rate over 17 times

Table 3. Sediment surface area extension and reworking estimates calculated for 3 differing sediment types: mud (PA1), muddy sand (PA4) and sand (PE2). Values are means (95\% CI) for adult burrows only. Burrow maintenance samples were only collected at PE2. $B_{\mathrm{g}}$ : burrow dry weight (DW); $C_{\mathrm{n}}$ : crab density; $B_{\mathrm{p}}$ : burrow permanency; $S R$ : sediment reworking rate; SLM: summer lunar month $(28 \mathrm{~d})_{i} S_{\mathrm{e}}$ : sediment excavated as maintenance pellets; $B M$ : sediment excavated during burrow maintenance; TSR: total sediment reworking rate including $B M$ and $S R$ values

\begin{tabular}{|lccc|}
\hline & Mud & Muddy sand & Sand \\
\hline Burrow density $\left(\mathrm{no.}^{-2}\right)$ & $207(143-271)$ & $144(134-154)$ & $30.7(5.71-58.3)$ \\
Burrow volume $\left(\mathrm{cm}^{3}\right)$ & $22.4(17.5-53.4)$ & $9.5(5.77-18.7)$ & $32.5(11.7-37.4)$ \\
Total burrow volume $\left(\mathrm{cm}^{3} \mathrm{~m}^{-2}\right)$ & $4635(2499-14439)$ & $1373(774-2874)$ & $997(66.6-2178)$ \\
Burrow surface area $\left(\mathrm{cm}^{2}\right)$ & $68.6(35.2-102)$ & $34.5(25.7-43.3)$ & $71.0(29.5-113)$ \\
Total burrow surface area $\left(\mathrm{cm}^{2} \mathrm{~m}^{-2}\right)$ & $14180(5027-27564)$ & $4968(3446-6668)$ & $2180(168-6588)$ \\
$\%$ increase surface area & $142(50.3-276)$ & $49.7(34.4-66.6)$ & $21.8(16.8-65.8)$ \\
$B_{\mathrm{g}}(\mathrm{g}$ DW) & $20.2(6.75-33.6)$ & $11.0(6.9-15.0)$ & $48.8(17.5-80.1)$ \\
$C_{\mathrm{n}}\left(\right.$ ind. $\left.\mathrm{m}^{-2}\right)$ & $141(61.6-221)$ & $109(29.0-190)$ & $48.0(18.2-77.8)$ \\
$B_{\mathrm{p}}(\mathrm{d})$ & $25.7(21.5-31.8)$ & $10.8(8.57-14.8)$ & $1.39(1.24-1.58)$ \\
Median burrow depth $(\mathrm{cm})$ & 4.7 & 3.6 & 3.9 \\
Available sediment $\left(\mathrm{kg} \mathrm{DW} \mathrm{m}^{-2}\right)$ & 42.3 & 41.4 & 57.7 \\
SR $\left(\mathrm{kg} \mathrm{m}^{-2} \mathrm{SLM}{ }^{-1}\right)$ & $3.1(0.37-9.7)$ & $7.5(0.38-9.3)$ & $47.2(5.7-141)$ \\
$\%$ SR $\left(\mathrm{SLM}^{-1}\right)$ & $7.4(0.87-22.9)$ & - & $81.8(9.8-244)$ \\
$S_{\mathrm{e}}\left(\mathrm{kg} \mathrm{crab}^{-1} \mathrm{SLM}^{-1}\right)$ & - & - & $0.56(0.45-0.67)$ \\
BM $\left(\mathrm{kg} \mathrm{m}^{-2} \mathrm{SLM}^{-1}\right)$ & - & - & $26.9(8.3-52.0)$ \\
TSR $\left(\mathrm{kg} \mathrm{m}^{-2} \mathrm{SLM}^{-1}\right)$ & - & - & $74.2(14.0-192)$ \\
$\%$ TSR $\left(\mathrm{SLM}^{-1}\right)$ & - & & $129(24.2-333)$ \\
\hline
\end{tabular}


greater than that of muddy sand or mud per lunar month, with an average of $74.2 \mathrm{~kg} \mathrm{~m}^{-2} \mathrm{SLM}^{-1}$. Based on this calculation, the entire sedimentary area available to Austrohelice crassa (to a median depth of $38.5 \mathrm{~mm}$ in this instance) would be turned over 1.3 times each month at Stn PE2.

\section{DISCUSSION}

The present study demonstrates that the sediment environment in which Austrohelice crassa resides can alter its primary mode of bioturbation from a burrow builder in cohesive sediments to that of a bulldozer in sandier sediments. These differences in organism behaviour and activity affect functionality across sediment types. This suggests a need to understand both the natural history and environmental context of an organism if we are to develop adequate surrogates for ecosystem functioning using biological traits analysis (Suding et al. 2008). Recognition of the importance of natural history and environmental context will also help us comprehend the myriad of ecosystem services derived from seafloor ecosystems and better predict how they may respond to habitat change.

\section{Extension of the sediment-water interface}

When all highly correlated mean burrow metrics (length, depth, volume and surface area) were assessed across the sediment gradient, no obvious differences associated with sediment type were apparent due to the variation in burrow forms and sizes within each station. However, when surface area was scaled with burrow density (giving total burrow surface area), trends across the sediment gradient were evident, with the greatest surface area in mud and lowest in the coarsest sand (Fig. 3c). Indeed, when considering the 3 stations where sediment reworking was estimated, the muddiest station displayed a much greater total burrow surface area than either of the other 2 stations, despite mean burrow surface area and volume being greater in sand (Table 3). The muddy sand station showed a reduced mean burrow surface area and volume compared to the other 2 stations, likely caused by a reduction in mean burrow length and fewer funnelshaped burrow apertures. Burrow lumen were observed to be larger and more symmetrical in sand than at either of the other 2 stations, which potentially acts as a stabilising mechanism for structures in less cohesive sediments.

Morrisey et al. (1999) found Austrohelice crassa burrows were of a simpler morphology in sand, with burrows up to 14.8 times larger in mud. We found that although the number of burrow forms present did not show predictable relationships with sediment type across the entire sediment gradient, the greatest numbers of burrow forms were cast in the muddiest sediments and the fewest in the coarsest sediments, but these were not always the simplest forms. However, some loss of complexity was indicated by the lack of burrows with multiple surface openings in coarser sediments, potentially elevating the observed burrow:crab ratio found in muddier habitats (Figs. 4 \& 5).

\section{Sediment reworking}

Cohesive sediments were shown to be much more static than non-cohesive sediments. Rates of reworking were very similar in mud and muddy sand as, despite a significantly larger number of adult crabs being present in the mud, burrow permanency was longer (Table 3). Although burrows had the greatest median depth in mud, the density of sediment was lower than in either of the other 2 habitats, leading to differences in the available dry weight of sediment for crabs to exhume. This equated to over an order of magnitude difference in the percentage volume of sediment reworked by Austrohelice crassa between sand and muddier sediments. The main driver of this difference (in conjunction with organism density) is burrow permanency. A $20 \%$ increase in silt-clay content meant burrow permanency in muddy sand was almost 8.5 times that of sand alone. A further $35 \%$ increase in silt-clay doubled the mean burrow life from that of muddy sand, making burrows at the muddy station over 18 times more stable than those in fine, clean sand. Our assumption, that for every burrow that collapses a new one is formed, appeared valid, as total burrow density in each station maintained a steady state throughout the observation period. This also indicates that the burrow markers did not have any adverse affects on crab behaviour.

Burrow maintenance rates in sand contributed greatly to the total reworking rates. In combination with the burrow construction-based estimates, this activity meant Austrohelice crassa would completely turn over the available sediment volume 1.3 times each summer lunar month. The excavated sediment did not differ greatly in grain size or TOM from that of the sediment surface. This again highlights that sediment mixing is frequent. Although burrow maintenance data was not collected at the mud and muddy sand stations, we assume that bedload transport would be greatly reduced in more cohesive, lower energy environments and hence the frequency of burrow maintenance would be less. Therefore, whilst the inclusion of burrow maintenance rates in mud and muddy sand 
may have increased total sediment reworking rates fractionally (had these measurements been possible), the relative differences between the 3 stations would likely remain the same.

\section{Primary effects of Austrohelice crassa in cohesive sediments}

In mud and muddy sand Austrohelice crassa primarily altered its environment through the extension of the sediment-water interface. This increases the depth of oxygen penetration, enhancing biogeochemical exchange, and creates new and varied habitats for microbial communities, altering the metabolic breakdown of organic matter (Kristensen \& Blackburn 1987, Glud 2008). Passive burrow irrigation through tidal flushing may further speed up reaction rates irrespective of burrow occupancy, enhancing solute transport across the sediment-water interface (Kristensen 1984). This contribution to nutrient exchange is likely related to burrow morphology, permanency and orientation in to the prevailing flow (Ray \& Aller 1985, Huettel \& Gust 1992, Libelo et al. 1994, Ridd 1996). Extension of the sediment-water interface is the typical mechanism by which burrow builders influence their environment. Previous studies on decapod crustaceans have documented increases in sediment-water interface ranging from 20 to $310 \%$ (Katz 1980, Dworschak \& Pervesler 1988, Griffis \& Chavez 1988, Witbaard \& Duineveld 1989, Coelho et al. 2000). Our estimates for all 3 stations fall within this range. However, the present study has proven the importance of including the dynamic element of sediment reworking in discussions of such estimates. Due to the short-lived nature of burrows in sand, the increases in burrow surface area alone may be misleading.

\section{Primary effects of Austrohelice crassa in non-cohesive sediments}

Regular burrow collapse in sandier sediments meant that although Austrohelice crassa continued to create burrows, their impacts through increased burrow surface area were short-lived (2 to 3 tides). A. crassa primarily destabilised the sediment surface in sand, repressing the redox potential discontinuity and subducting organic matter through frequent burrow collapse, characteristics normally attributed to bulldozing bioturbators (Osinga et al. 1997, Widdicombe \& Austen 1998, Hollertz \& Duchêne 2001, Lohrer et al. 2004). For example, Echinocardium cordatum has been demonstrated to affect the top $6 \mathrm{~cm}$ of sediment, creating continual slumping similar to that of derelict burrows
(Lohrer et al. 2005). In all habitats where bioturbation occurs and particularly where turnover is rapid, meiofaunal and macrofaunal communities will be greatly affected by this continual disturbance (Thrush 1988, Botto \& Iribarne 1999, Lohrer et al. 2008).

Increased sediment reworking in non-cohesive sediments also suggests a higher turnover of carbon standing stock. Microphytobenthic communities are likely to respond to frequent displacement and burial, as the energetic cost of reorientation at the sediment surface will differentially affect species. Biofilms that are perpetually disrupted may not bind the sediment matrix adequately, leading to decreased sediment stability and increased bedload transport (Miller et al. 1996). However, the presence of bioturbating macrofauna has previously been shown to increase $\mathrm{O}_{2}$ uptake and $\mathrm{CO}_{2}$ production by 30 to $70 \%$, which may act as a trade-off for microphytes living in dynamic systems (Kristensen et al. 1992, Hansen \& Kristensen 1997).

Sediment reworking can affect the bioavailability of pollutants and contaminants in sediments (Petersen et al. 1998, Menone et al. 2006). Sediment reworking by Austrohelice crassa has previously been shown to affect the bioavailability of heavy metals through the influence of their bioturbation activity on acid volatile sulphides and $\mathrm{FeS}_{2}$ (Morrisey et al. 1999). A. crassa also plays a crucial role in remediation of terrigenous sediment impacts. This species can survive deposition events and, through mixing and re-oxygenation, alter the rates of transport and sequestration of terrigenous material (Gibbs et al. 2001, Norkko et al. 2002, Thrush et al. 2003).

\section{Seasonal elements and temperature-related effects: adjustments to estimations}

Several studies have shown that burrowing crab species including Austrohelice crassa display patterns of seasonality in their burrow building (Wolfrath 1992, Sivaguru 2000, McCraith et al. 2003). This manifests as changes in burrow morphology such as burrow length, altered activity and burrow building rates. Spring and summer appear to be the most active seasons for burrowing crabs in relation to sediment mixing, irrespective of sediment location. A. crassa densities do not differ seasonally (Sivaguru 2000), which indicates that any observed changes in activity rates are likely to be caused by temperature change, as inherent sediment properties do not differ greatly between seasons. When considering the calculations in the present study, we captured the likely maximal rates of bioturbation activity to highlight the differences across sediment types. If these values were extrapolated to an annual level, it is likely that mean sediment mixing and surface area increase would be overestimated. 
Mean annual sea and air temperatures in the locality of the present study range from $20.1 \pm 1.7$ to $13.6 \pm 1.2^{\circ} \mathrm{C}$ and $19.9 \pm 2.0$ to $10.9 \pm 2.1^{\circ} \mathrm{C}$, respectively (Giles 2002, NIWA 2009); therefore, seasonal reworking patterns may be more detectable in the colder southern regions of New Zealand where seasonal temperature variation can be greater.

Circatidal and circadian rhythms can alter the behavioural responses of some crustaceans. Unlike many burrowing crabs, Austrohelice crassa behaviour is not affected by the day-night cycle; indeed, A. crassa's peak activity period is at high tide (Williams et al. 1985). Therefore, our maintenance rate assumption that behaviour is similar on both day and night tides was justified. This also indicates that seasonal responses to changes in photoperiod are unlikely to dramatically alter behaviour of this organism. As burrow permanency was monitored for $2 \mathrm{mo}$, differences in activity rates through alterations of tidal amplitude were captured.

\section{CONCLUSIONS}

To assess broad-scale patterns in ecosystem functioning, species have previously been grouped according to their functional or biotic traits to reduce the variability within biological data (Pearson 2001 and references therein, Bremner et al. 2006, McGill et al. 2006). To model relationships between such functional groups and sediment dynamics, Swift (1993) proposed organisms should be rated according to their bioturbation potential. Such models, including those with increased nuances such as organism biomass (Gilbert et al. 2007, Sanders et al. 2007), do not yet acknowledge that the functionality of individuals within a species may differ according to their sedimentary context. These alterations not only consist of potential shifts in the rates of particular processes, but may even include, as illustrated by Austrohelice crassa, fundamental shifts in the types of processes occurring. Few studies have touched upon how environmental variability directly affects organism behaviour to the degree that its functionality within an environment is altered (Biles et al. 2003, Escapa et al. 2008, Sassa \& Watabe 2008). The present study demonstrates that the behaviour and performance of a dominant organism may determine the degree of ecosystem functioning under different environmental conditions. This is likely to be expressed by larger-bodied bioengineers or those present in high densities across a wide habitat spectrum. Understanding the functional plasticity of key bioturbating species is vital if we are to ensure that predictive models elicit an accurate organism response under different environmental scenarios.
Acknowledgements. We thank D. Bell, D. Oezkundakci, J. Parenzee, P. Ross and M. Townsend for help in the field and laboratory and the 4 anonymous reviewers who contributed to the revision of this manuscript. Funding for this study was provided through a NIWA Foundation for Research, Science and Technology (FRST) funded PhD studentship under project no. C01X0501.

\section{LITERATURE CITED}

Aller RC, Yingst JY (1978) Biogeochemistry of tube dwellings: a study of the sedentary polychaete Amphitrite ornata (Leidy). J Mar Res 36:201-254

Arar E, Collins G (1997) Method 445.0: in vitro determination of chlorophyll $a$ and pheophytin $a$. Marine and freshwater algae by fluorescence. Revision 1.2. US Environmental Protection Agency, Cincinnati, OH

Biles CL, Solan M, Isaksson I, Paterson DM, Emes C, Raffaelli DG (2003) Flow modifies the effect of biodiversity on ecosystem functioning: an in situ study of estuarine sediments. J Exp Mar Biol Ecol 285-286:165-177

> Bonsdorff E, Pearson TH (1999) Variation in the sublittoral macrozoobenthos of the Baltic Sea along environmental gradients: a functional-group approach. Austral Ecol 24: 312-326

> Botto F, Iribarne O (1999) Effect of the burrowing crab Chasmagnathus granulata (Dana) on the benthic community of a SW Atlantic coastal lagoon. J Exp Mar Biol Ecol 241: 263-284

Botto F, Iribarne O (2000) Contrasting effects of two burrowing crabs (Chasmagnathus granulata and Uca uruguayensis) on sediment composition and transport in estuarine environments. Estuar Coast Shelf Sci 51:141-151

Botto F, Valiela I, Iribarne O, Martinetto P, Alberti J (2005) Impact of burrowing crabs on $\mathrm{C}$ and $\mathrm{N}$ sources, control, and transformations in sediments and food webs of SW Atlantic estuaries. Mar Ecol Prog Ser 293:155-164

Breitfuss MJ (2003) Defining the characteristics of burrows to better estimate abundance of the grapsid crab, Helograpsus haswellianus (Decapoda, Grapsidae), on East Australian saltmarsh. Crustac Int J Crustac Res 76:499-507

Bremner J, Rogers SI, Frid CLJ (2006) Matching biological traits to environmental conditions in marine benthic ecosystems. J Mar Syst 60:302-316

Coelho VR, Cooper RA, Rodrigues SA (2000) Burrow morphology and behaviour of the mud shrimp Upogebia omissa (Decapoda: Thalassinidea: Upogebiidae). Mar Ecol Prog Ser 200:229-240

D'Andrea AF, DeWitt TH (2009) Geochemical ecosystem engineering by the mud shrimp Upogebia pugettensis (Crustacea: Thalassinidae) in Yaquina Bay, Oregon: density-dependent effects on organic matter remineralization and nutrient cycling. Limnol Oceanogr 54:1911-1932

Day P (1965) Particle fractionation and particle-size analysis. In: Black CA (ed) Methods of soil analysis: Part I. American Society of Agronomy, Madison, WI, p 545-567

Dean WE (1974) Determination of carbonate and organic matter in calcareous sediments and sedimentary rocks by loss on ignition: comparison with other methods. J Sed Res 44: 242-248

Dworschak P, Pervesler P (1988) Burrows of Callianassa bouvieri Nobili 1904 from Safaga (Egypt, Red Sea) with some remarks on the biology of the species. Senckenb Marit 20: $1-17$

> Escapa M, Perillo GME, Iribarne O (2008) Sediment dynamics modulated by burrowing crab activities in contrasting SW 
Atlantic intertidal habitats. Estuar Coast Shelf Sci 80: 365-373

Fanjul E, Grela MA, Canepuccia A, Iribarne O (2008) The Southwest Atlantic intertidal burrowing crab Neohelice granulata modifies nutrient loads of phreatic waters entering coastal area. Estuar Coast Shelf Sci 79:300-306

> Gardner LR, Sharma P, Moore WS (1987) A regeneration model of the effect of bioturbation by fiddler crabs on ${ }^{210} \mathrm{~Pb}$ profiles in salt marsh sediments. J Environ Radioact 5: 25-36

Gibbs M, Thrush S, Ellis J (2001) Terrigenous clay deposition on estuarine sandflats: using stable isotopes to determine the role of the mud crab, Helice crassa Dana, in the recovery process. Isotopes Environ Health Stud 37:113-131

Gilbert F, Hulth S, Grossi V, Poggiale JC and others (2007) Sediment reworking by marine benthic species from the Gullmar Fjord (western Sweden): importance of faunal biovolume. J Exp Mar Biol Ecol 348:133-144

Giles KF (2002) Seasonal dynamics of zooplankton in Tauranga Harbour, New Zealand. MSc thesis, University of Waikato, Hamilton

Glud RN (2008) Oxygen dynamics of marine sediments. Mar Biol Res 4:243-289

Griffis RB, Chavez FL (1988) Effects of sediment type on burrows of Callianassa californiensis Dana and Callianassa gigas Dana. J Exp Mar Biol Ecol 117:239-253

Gutierrez JL, Jones CG, Groffman PM, Findlay SEG, Iribarne OO, Ribeiro PD, Bruschetti CM (2006) The contribution of crab burrow excavation to carbon availability in surficial salt-marsh sediments. Ecosystems 9:647-658

> Hansen K, Kristensen E (1997) Impact of macrofaunal recolonization on benthic metabolism and nutrient fluxes in a shallow marine sediment previously overgrown with macroalgal mats. Estuar Coast Shelf Sci 45:613-628

> Hewitt JE, Thrush SF, Dayton PD (2008) Habitat variation, species diversity and ecological functioning in a marine system. J Exp Mar Biol Ecol 366:116-122

Hollertz K, Duchêne JC (2001) Burrowing behaviour and sediment reworking in the heart urchin Brissopsis lyrifera Forbes (Spatangoida). Mar Biol 139:951-957

Huettel M, Gust G (1992) Solute release mechanisms from confined sediment cores in stirred benthic chambers and flume flows. Mar Ecol Prog Ser 82:187-197

> Iribarne O, Bortolus A, Botto F (1997) Between-habitat differences in burrow characteristics and trophic modes in the southwestern Atlantic burrowing crab Chasmagnathus granulata. Mar Ecol Prog Ser 155:137-145

Jones MB, Simons MJ (1983) Latitudinal variation in reproductive characteristics of a mud crab, Helice crassa (Grapsidae). Bull Mar Sci 33:656-670

Katz LC (1980) Effects of burrowing by the fiddler crab, Uca pugnax (Smith). Estuar Coast Mar Sci 11:233-237

Kostka JE, Gribsholt B, Petrie E, Dalton D, Skelton H, Kristensen E (2002) The rates and pathways of carbon oxidation in bioturbated saltmarsh sediments. Limnol Oceanogr 47:230-240

Kristensen E (1984) Life cycle, growth and production in estuarine populations of the polychaetes Nereis virens and $N$. diversicolor. Holarctic Ecol 7:249-256

Kristensen E (2008) Mangrove crabs as ecosystem engineers; with emphasis on sediment processes. J Sea Res 59:30-43

> Kristensen E, Blackburn TH (1987) The fate of organic carbon and nitrogen in experimental marine sediment systems: influence of bioturbation and anoxia. J Mar Res 45: 231-257

Kristensen E, Kostka J (2005) Macrofaunal burrows and irrigation in marine sediment; microbiological and biogeo- chemical interactions. In: Kristensen E, Haese RR, Kostka JE (eds) Interactions between macro- and microorganisms in marine sediments. American Geophysical Union, Washington, DC, p 125-158

Kristensen E, Jensen MH, Andersen TK (1985) The impact of polychaete (Nereis virens Sars) burrows on nitrification and nitrate reduction in estuarine sediments. J Exp Mar Biol Ecol 85:75-91

Kristensen E, Andersen FØ, Blackburn TH (1992) Effects of benthic macrofauna and temperature on degradation of macroalgal detritus: the fate of organic carbon. Limnol Oceanogr 37:1404-1419

> Lee SY (1998) Ecological role of grapsid crabs in mangrove ecosystems: a review. Mar Freshw Res 49:335-343

Levenberg K (1944) A method for the solution of certain nonlinear problems in least squares. Q Appl Math 2:164-168

Levinton J, Kelaher B (2004) Opposing organizing forces of deposit-feeding marine communities. J Exp Mar Biol Ecol 300:65-82

Libelo EL, Macintyre WG, Seitz RD, Libelo LF (1994) Cycling of water through the sediment-water interface by passive ventilation of relics biological structures. Mar Geol 120: $1-12$

Lim SSL, Diong CH (2003) Burrow-morphological characters of the fiddler crab, Uca annulipes ( $\mathrm{H}$. Milne Edwards, 1837) and ecological correlates in a lagoonal beach on Pulau Hantu, Singapore. Crustac Int J Crustac Res 76: 1055-1069

Lohrer AM, Thrush SF, Gibbs MM (2004) Bioturbators enhance ecosystem function through complex biogeochemical interactions. Nature 431:1092-1095

> Lohrer AM, Thrush SF, Hunt L, Hancock N, Lundquist C (2005) Rapid reworking of subtidal sediments by burrowing spatangoid urchins. J Exp Mar Biol Ecol 321:155-169

Lohrer AM, Chiaroni LD, Hewitt JE, Thrush SF (2008) Biogenic disturbance determines invasion success in a subtidal soft-sediment system. Ecology 89:1299-1307

McCraith BJ, Gardner LR, Wethey DS, Moore WS (2003) The effect of fiddler crab burrowing on sediment mixing and radionuclide profiles along a topographic gradient in a southeastern salt marsh. J Mar Res 61:359-390

McGill BJ, Enquist BJ, Weiher E, Westoby M (2006) Rebuilding community ecology from functional traits. Trends Ecol Evol 21:178-185

- Menone ML, Miglioranza KSB, Botto F, Iribarne O, Aizpún de Moreno JE, Moreno VJ (2006) Field accumulative behavior of organochlorine pesticides. The role of crabs and sediment characteristics in coastal environments. Mar Pollut Bull 52:1717-1724

> Miller D, Geider R, MacIntyre H (1996) Microphytobenthos: the ecological role of the 'secret garden' of unvegetated, shallow-water marine habitats. II. Role in sediment stability and shallow-water food webs. Estuaries Coasts 19: $202-212$

> Morrisey DJ, DeWitt TH, Roper DS, Williamson RB (1999) Variation in the depth and morphology of burrows of the mud crab Helice crassa among different types of intertidal sediment in New Zealand. Mar Ecol Prog Ser 182:231-242

$>$ Mouton E, Felder D (1996) Burrow distributions and population estimates for the fiddler crabs Uca spinicarpa and Uca longisignalis in a Gulf of Mexico salt marsh. Estuaries Coasts 19:51-61

> Mullan Crain C, Bertness MD (2006) Ecosystem engineering across environmental gradients: implications for conservation and management. Bioscience 56:211-218

> Nickell LA, Atkinson RJA (1995) Functional morphology of burrows and trophic modes of three thalassinidean shrimp 
species, and a new approach to the classification of thalassinidean burrow morphology. Mar Ecol Prog Ser 128:181-197

NIWA (National Institute of Water and Atmospheric Research) (2009) The National Climate Database. NIWA, Auckland, available at http://cliflo.niwa.co.nz

Norkko A, Thrush SF, Hewitt JE, Cummings VJ and others (2002) Smothering of estuarine sandflats by terrigenous clay: the role of wind-wave disturbance and bioturbation in site-dependent macrofaunal recovery. Mar Ecol Prog Ser 234:23-41

Nye PA (1977) Reproduction, growth and distribution of the grapsid crab Helice crassa (Dana, 1851) in the southern part of New Zealand. Crustac Int J Crustac Res 33:75-89

Osinga R, Kop AJ, Malschaert JFP, Van Duyl FC (1997) Effects of the sea urchin Echinocardium cordatum on bacterial production and carbon flow in experimental benthic systems under increasing organic loading. J Sea Res 37: 109-121

Pearson TH (2001) Functional group ecology in soft-sediment marine benthos: the role of bioturbation. Oceanogr Mar Biol Annu Rev 39:233-267

Petersen K, Kristensen E, Bjerregaard P (1998) Influence of bioturbating animals on flux of cadmium into estuarine sediment. Mar Environ Res 45:403-415

Ray R, Aller R (1985) Physical irrigation of relict burrows: implications for sediment chemistry. Mar Geol 62:371-379

Ridd PV (1996) Flow through animal burrows in mangrove creeks. Estuar Coast Shelf Sci 43:617-625

Roth S, Wilson JG (1998) Functional analysis by trophic guilds of macrobenthic community structure in Dublin Bay, Ireland. J Exp Mar Biol Ecol 222:195-217

Salgado Kent CP, McGuinness KA (2006) A comparison of methods for estimating relative abundance of grapsid crabs. Wetl Ecol Manage 14:1-9

Sanders J, Kendall M, Hawkins A, Spicer J (2007) Can functional groups be used to indicate estuarine ecological status? Hydrobiologia 588:45-58

Sassa S, Watabe Y (2008) Threshold, optimum and critical geoenvironmental conditions for burrowing activity of sand bubbler crab, Scopimera globosa. Mar Ecol Prog Ser 354:191-199

Sivaguru K (2000) Feeding and burrowing in a North Island New Zealand population of the estuarine mud crab, Helice crassa. PhD thesis, University of Auckland, Auckland

Snelgrove PVR (1999) Getting to the bottom of marine biodiversity: sedimentary habitats. Bioscience 49:129-138

Editorial responsibility: Just Cebrian,

Dauphin Island, Alabama, USA
Suding KN, Lavorel S, Chapin FS, Cornelissen JHC and others (2008) Scaling environmental change through the community-level: a trait-based response-and-effect framework for plants. Global Change Biol 14:1125-1140

Swift DJ (1993) The macrobenthic infauna off Sellafield (north-eastern Irish Sea) with special reference to bioturbation. J Mar Biol Assoc UK 73:143-162

Takeda S, Kurihara Y (1987) The distribution and abundance of Helice tridens (De Haan) burrows and substratum conditions in a northeastern Japan salt marsh (Crustacea: Brachyura). J Exp Mar Biol Ecol 107:9-19

Thrush SF (1988) The comparison of macrobenthic recolonization patterns near and away from crab burrows on a sublittoral sand flat. J Mar Res 46:669-681

Thrush SF, Hewitt JE, Norkko A, Cummings VJ, Funnell GA (2003) Macrobenthic recovery processes following catastrophic sedimentation on estuarine sandflats. Ecol Appl 13:1433-1455

Thrush SF, Gray JS, Hewitt JE, Ugland KI (2006) Predicting the effects of habitat homogenization on marine biodiversity. Ecol Appl 16:1636-1642

Tilman D (2000) Causes, consequences and ethics of biodiversity. Nature 405:208-211

Webb AP, Eyre BD (2004) The effect of natural populations of the burrowing and grazing soldier crab (Mictyris longicarpus) on sediment irrigation, benthic metabolism and nitrogen fluxes. J Exp Mar Biol Ecol 309:1-19

Widdicombe S, Austen MC (1998) Experimental evidence for the role of Brissopsis lyrifera (Forbes, 1841) as a critical species in the maintenance of benthic diversity and the modification of sediment chemistry. J Exp Mar Biol Ecol 228:241-255

Williams B, Naylor E, Chatterton T (1985) The activity patterns of New Zealand mud crabs under field and laboratory conditions. J Exp Mar Biol Ecol 89:269-282

Williamson RB, Wilcock RJ, Wise BE, Pickmere SE (1999) Effect of burrowing by the crab Helice crassa on chemistry of intertidal muddy sediments. Environ Toxicol Chem 18:2078-2086

Witbaard R, Duineveld GCA (1989) Some aspects of the biology and ecology of the burrowing shrimp Callianassa subterranea (Montagu) (Thalassinidea) from the southern North Sea. Sarsia 74:209-219

Wolfrath B (1992) Burrowing of the fiddler crab Uca tangeri in the Ria Formosa in Portugal and its influence on sediment structure. Mar Ecol Prog Ser 85:237-243

Submitted: December 15, 2009; Accepted: July 5, 2010 Proofs received from author(s): September 1, 2010 